\title{
Energetic Aspects Related to Heavy Metals Adsorption on the Surface of Volcanic Tuff I. The Influence of Activation Parameters in $\mathrm{Cu}^{2+}$ Adsorption
}

\author{
${ }^{1}$ Leonard Mihaly-Cozmuta, ${ }^{2}$ Teodor Visan, ${ }^{1}$ Anca Mihaly-Cozmuta, ${ }^{1}$ Camelia Varga \\ ${ }^{1}$ Vasile Viman and ${ }^{1}$ Gheorghe Vatca \\ ${ }^{1}$ Chemistry-Biology Department of North University of Baia Mare \\ Victorie Str. 76, Baia Mare, 4800, Romania \\ ${ }^{2}$ Applied Chemistry and Material Sciences Faculty, Polytechnic Institute of Bucharest, Romania
}

\begin{abstract}
The article develops some physico-chemical aspects presented along of copper ions adsorption in treatment of wastewaters using volcanic tuff. In the experiments volcanic tuff from Stoiana Pâglişa (Romania) has been used. Different concentrations of $\mathrm{NaCl}$ and $\mathrm{HCl}$ solutions were used for activation of tuff. The increase of activation solutions' concentrations indicates an intensification of specific adsorption of copper as consequence of energetic changes of the active centers spread on the tuff surface.
\end{abstract}

Key words: Copper adsorption, clinoptilolite, activation process

\section{INTRODUCTION}

Volcanic tuffs with theirs composition of natural zeolites, belong to hydrated aluminosilicates with three dimensional structure characterized by the associated anionic tetraedric of $(\mathrm{Si}, \mathrm{Al}) \mathrm{O}_{4}$. The inside structure, containing numerous pores connected one to another by 2.2-9 Å diameters channels and occupied with different cations, explains the ionic exchange property of the tuffs. The cations from the solutions which the tuffs are in contact of, can easily replace the cations from inside of the tuffs' pores, without changing theirs structure and electric charge. This fact recommends the tuffs for treatment of wastewaters polluted with heavy metals like an alternative method to classical methods ${ }^{[1-7]}$.

From chemical point of view, the zeolites contain alkaline and alkaline-earth metallic ions and are presented under the general formulae $\left(\mathrm{Me}^{+}\right.$, $\left.1.5 \mathrm{M}^{2+}\right)_{\mathrm{x}}\left(\mathrm{Al}_{\mathrm{x}} \mathrm{Si}_{\mathrm{y}} \mathrm{O}_{2(\mathrm{x}+\mathrm{y})}\right) \mathrm{zH}_{2} \mathrm{O}$, where $\mathrm{x}<\mathrm{y} ; \mathrm{Me}-\mathrm{Na}$, $\mathrm{K}, \mathrm{Li}$; $\mathrm{M}-\mathrm{Ca}, \mathrm{Mg}$, Ba, Sr.

\section{MATERIALS AND METHODS}

Volcanic tuff from Stoiana Pâglişa (Romania) characterized by a high content of clinoptilolite $\left(\mathrm{Na}_{6}\left[\mathrm{Al}_{6} \mathrm{Si}_{30} \mathrm{O}_{72}\right] \cdot 24 \mathrm{H}_{2} \mathrm{O}\right)$ was used for experiments ( Table $1^{[8]}$ ).

The physico-chemical aspects related to the copper adsorption on mentioned tuff were analyzed in order to increase the adsorption capacity. In this end, two steps were performed:

Activation of the tuff: Two types of $\mathrm{NaCl}$ and $\mathrm{HCl}$ solutions (Merk purity) with $0.1,0.5,1$ and $2 \mathrm{~mol} \mathrm{~L}^{-1}$ concentrations were used in the stage of activation tuff. For each experiment, an amount of $10 \mathrm{~g}$ tuff with the average granullometry of $0.048 \pm 0.008 \mathrm{~mm}$ was contacted, under the continuous stir, with $250 \mathrm{ml}$ activation solution. After $4 \mathrm{~h}$, the tuff was filtered, rinsed up to completely remove of $\mathrm{Cl}^{-}$ions (negative reaction in the presence of $\mathrm{AgNO}_{3}$ ) and dried about 24 $\mathrm{h}$ at $105^{\circ} \mathrm{C}$.

Adsorption of the copper ions on the tuff's activated surface: A volume of $300 \mathrm{~mL}$ synthetic solution $(\mathrm{pH}=5)$ containing $102.61 \mathrm{mg} \mathrm{L}^{-1} \mathrm{Cu}^{2+}$ was added over activated tuff. At every five min, solution samples were collected and polarographic analyzed (Radelkis $\mathrm{OH} 110$ ) in order to determine the remained copper contain. Also, the experiments were performed in the same conditions, with only one analysis of copper contain, after $4 \mathrm{~h}$, time enough for the system to reach the equilibrium state.

\section{RESULTS AND DISCUSSION}

The obtained results are presented in Table 2. As the values shows, the increase of $\mathrm{NaCl}$ concentration from 0.1 to $2 \mathrm{~mol} \mathrm{~L}^{-1}$ induces in the next step of adsorption an increase of copper adsorption capacity. It rise with $8.65 \%$, from $5.5320 \mathrm{mg} \mathrm{Cu}^{2+} \mathrm{g}^{-1}$ tuff to $6.0108 \mathrm{mg} \mathrm{Cu}^{2+} \mathrm{g}^{-1}$ tuff. Similar behavior can be noticed in case of activation with $\mathrm{HCl}$ solutions, but for the same concentrations a $6.5 \%$ increase of copper adsorption capacity can be observed from $5.5128 \mathrm{mg}$ $\mathrm{Cu}^{2+} \mathrm{g}^{-1}$ tuff to $5.8716 \mathrm{mg} \mathrm{Cu}^{2+} \mathrm{g}^{-1}$ tuff (Fig. 1). The lower copper adsorption capacity of tuff activated with $\mathrm{HCl}$ solutions indicates a higher affinity of tuff for $\mathrm{Na}^{+}$ rather then $\mathrm{H}^{+}$. 
American J. Environ. Sci. 1 (2): 159-163, 2005

Table 1: Mineralogical and chemical composition of Stoiana Paglisa - Romania volcanic tuff

\begin{tabular}{llclc}
\hline Nr. crt. & Mineral & Contain $(\%)$ & Component & Content $(\%)$ \\
\hline 1 & Zeolite (clinoptilolite) & $50-62$ & Ignition losses & 10.14 \\
2 & Volcanic glass & $36-48$ & $\mathrm{SiO}_{2}$ & 65.59 \\
3 & Feldspat & $1-1.5$ & $\mathrm{Al}_{2} \mathrm{O}_{3}$ & 13.70 \\
4 & Biotite & $1-1.5$ & $\mathrm{Fe}_{2} \mathrm{O}_{3}$ & 1.47 \\
5 & Limonite & $\mathrm{CaO}$ & 4.72 \\
6 & Calcite & $0.5-1$ & $\mathrm{MgO}$ & 0.92 \\
7 & Hornblende & $1-1.5$ & $\mathrm{~K}_{2} \mathrm{O}$ & 1.65 \\
8 & Montmorillonite & $<0.5$ & $\mathrm{Na}_{2} \mathrm{O}$ & 1.60 \\
9 & - & -0.5 & $\mathrm{TiO}_{2}$ & 0.14 \\
\hline
\end{tabular}

Table 2: The influence of activation solutions' concentrations on the activation process of the tuff

\begin{tabular}{|c|c|c|c|c|c|c|c|c|c|c|c|c|c|c|c|c|}
\hline \multirow{3}{*}{$\begin{array}{l}\text { Time } \\
\text { minutes }\end{array}$} & \multicolumn{16}{|c|}{ Copper ions concentration $\left(\mathrm{mg} \mathrm{Cu}{ }^{2+} \mathrm{L}^{-1}\right)$} \\
\hline & \multicolumn{8}{|c|}{ Concentration of $\mathrm{NaCl}$ activation solution $\left(\mathrm{mol} \mathrm{L}^{-1}\right)$} & \multicolumn{8}{|c|}{ Concentration of $\mathrm{HCl}$ activation solution $\left(\mathrm{mol} \mathrm{L}^{-1}\right)$} \\
\hline & 0.1 & 0.1 & 0.5 & 0.5 & 1 & 1 & 2 & 2 & 0.1 & 0.1 & 0.5 & 0.5 & 1 & 1 & 2 & 2 \\
\hline 0 & 102.61 & 102.61 & 102.61 & 102.61 & 102.61 & 102.61 & 102.61 & 102.61 & 102.61 & 102.61 & 102.61 & 102.61 & 102.61 & 102.61 & 102.61 & 102.61 \\
\hline 5 & 88.98 & 79.75 & 82.78 & 71.10 & 76.95 & 63.52 & 72.83 & 58.42 & 90.59 & 82.10 & 87.39 & 77.49 & 84.29 & 73.16 & 79.82 & 67.21 \\
\hline 10 & 76.95 & 61.47 & 66.68 & 48.40 & 57.08 & 38.13 & 50.89 & 31.86 & 79.82 & 65.28 & 74.18 & 57.92 & 68.89 & 51.38 & 61.58 & 42.98 \\
\hline 15 & 66.38 & 46.97 & 52.89 & 32.30 & 41.86 & 22.10 & 34.97 & 16.53 & 70.18 & 51.54 & 62.75 & 42.81 & 56.02 & 35.50 & 47.10 & 26.77 \\
\hline 20 & 57.09 & 35.55 & 41.87 & 21.10 & 30.31 & 12.30 & 23.58 & 8.08 & 61.58 & 40.40 & 52.89 & 31.27 & 45.29 & 24.08 & 35.68 & 16.17 \\
\hline 25 & 48.96 & 26.63 & 32.91 & 13.45 & 21.65 & 6.54 & 15.58 & 3.68 & 53.92 & 31.43 & 44.42 & 22.54 & 36.41 & 16.02 & 26.77 & 9.45 \\
\hline 30 & 41.87 & 19.74 & 25.67 & 8.35 & 15.23 & 3.28 & 10.06 & 1.54 & 47.10 & 24.25 & 37.15 & 16.03 & 29.09 & 10.42 & 19.86 & 5.30 \\
\hline 35 & 35.68 & 14.45 & 19.86 & 5.02 & 10.54 & 1.55 & 6.33 & 0.57 & 41.05 & 18.54 & 30.95 & 11.22 & 23.09 & 6.62 & 14.57 & 2.85 \\
\hline 40 & 30.31 & 10.45 & 15.23 & 2.92 & 7.17 & 0.67 & 3.87 & 0.18 & 35.68 & 14.05 & 25.67 & 7.72 & 18.20 & 4.08 & 10.55 & 1.45 \\
\hline $\begin{array}{l}\mathrm{T} \\
\left({ }^{0} \mathrm{C}\right)\end{array}$ & 20 & 50 & 20 & 50 & 20 & 50 & 20 & 50 & 20 & 50 & 20 & 50 & 20 & 50 & 20 & 50 \\
\hline
\end{tabular}

Table 3: The thermodynamic parameters obtained in case of tuff activation with $\mathrm{NaCl}$ and $\mathrm{HCl}$ solutions

\begin{tabular}{|c|c|c|c|c|c|c|c|c|c|c|}
\hline \multirow[t]{2}{*}{ Parameter } & \multicolumn{5}{|c|}{ Concentration of $\mathrm{NaCl}$ solutions $\left(\mathrm{mol} \mathrm{L}^{-1}\right)$} & \multicolumn{5}{|c|}{ Concentration of $\mathrm{HCl}$ solutions $\left(\mathrm{mol} \mathrm{L}^{-1}\right)$} \\
\hline & 0 & 0.1 & 0.5 & 1 & 2 & 0 & 0.1 & 0.5 & 1 & 2 \\
\hline $\mathrm{q}\left(\mathrm{mg} \mathrm{Cu}^{2+} \mathrm{g}^{-1}\right) 50^{0} \mathrm{C}$ & 5.8470 & 5.9664 & 6.1410 & 6.1494 & 6.1530 & 5.8470 & 5.8890 & 5.9250 & 5.9676 & 6.0816 \\
\hline n $20^{\circ} \mathrm{C}$ & 0.8741 & 0.8729 & 0.8718 & 0.8707 & 0.8691 & 0.8741 & 0.8734 & 0.8735 & 0.8728 & 0.8720 \\
\hline n $50^{\circ} \mathrm{C}$ & 0.8729 & 0.8712 & 0.8682 & 0.8633 & 0.8548 & 0.8729 & 0.8719 & 0.8708 & 0.8697 & 0.8666 \\
\hline $\mathrm{k} 20^{\circ} \mathrm{C}$ & 0.00945 & 0.01251 & 0.01868 & 0.02482 & 0.02925 & 0.00945 & 0.01097 & 0.01414 & 0.01723 & 0.02186 \\
\hline $\mathrm{k} 50^{\circ} \mathrm{C}$ & 0.01695 & 0.02181 & 0.03113 & 0.03941 & 0.04353 & 0.01695 & 0.01940 & 0.02424 & 0.02899 & 0.03556 \\
\hline $\mathrm{Ea}\left(\mathrm{KJ} \mathrm{mol}^{-1}\right)$ & 15.339 & 14.593 & 13.408 & 12.139 & 10.437 & 15.339 & 14.967 & 14.150 & 13.660 & 12.774 \\
\hline$\Delta \mathrm{Ea}\left(\mathrm{KJ} \mathrm{mol}^{-1}\right)$ & 0 & 0.746 & 1.931 & 3.200 & 4.902 & 0 & 0.372 & 1.189 & 1.679 & 2.565 \\
\hline $\mathrm{X}_{\mathrm{T}}$ & 0.0033 & 0.0044 & 0.0068 & 0.0109 & 0.0205 & 0.0033 & 0.0038 & 0.0051 & 0.0062 & 0.0086 \\
\hline$X_{P}$ & 0.9502 & 0.9696 & 0.9980 & 0.9994 & 1 & 0.9502 & 0.9570 & 0.9629 & 0.9698 & 0.9883 \\
\hline
\end{tabular}

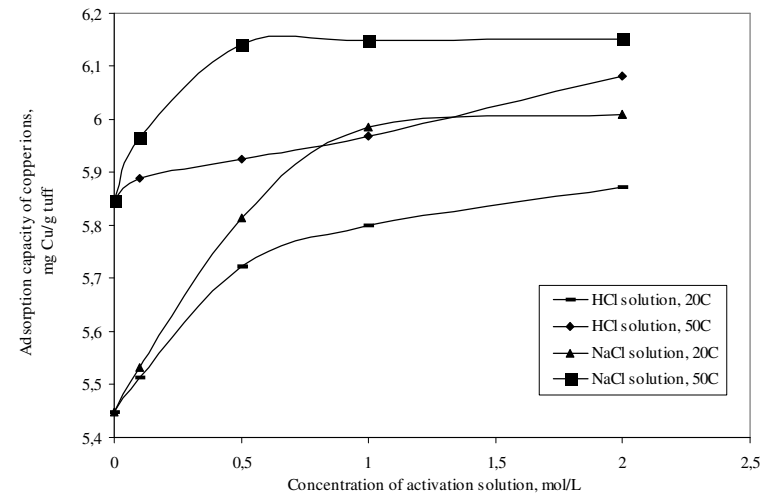

Fig. 1:The influence of activation solutions' concentrations on the adsorption capacity

Temperature is another parameter which influences the copper adsorption. As the Fig. 1 indicates, in case of the tuff activated with 2 mol L- ${ }^{-1} \mathrm{NaCl}$ solution the increase of temperature from $20^{\circ} \mathrm{C}$ to $50^{\circ} \mathrm{C}$ generated an

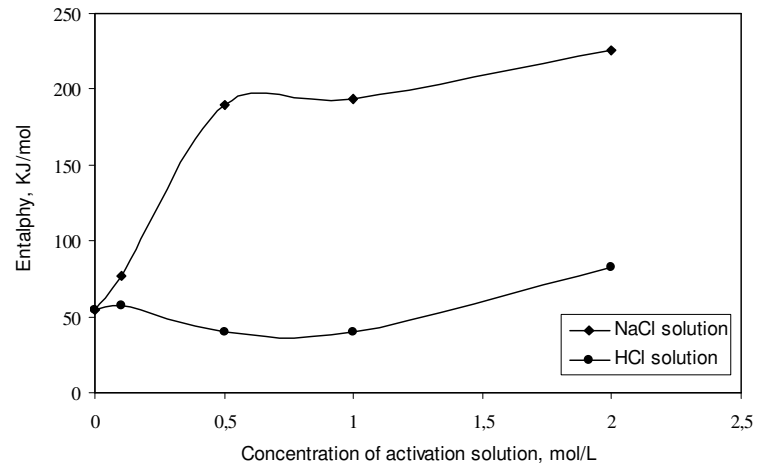

Fig. 2: The enthalpy of the copper adsorption process on volcanic tuff

increase of adsorption capacity with $2.3 \%$, from 6.0108 $\mathrm{mg} \mathrm{Cu} \mathrm{g}^{2+} \mathrm{g}^{-1}$ tuff to $6.1530 \mathrm{mg} \mathrm{Cu}^{2+} \mathrm{g}^{-1}$ tuff. In case of activation with $2 \mathrm{~mol} \mathrm{~L}^{-1} \mathrm{HCl}$ solution, the increase is about $3.57 \%$, from $5.8716 \mathrm{mg} \mathrm{Cu}^{2+} \mathrm{g}^{-1}$ tuff to 6.0816 $\mathrm{mg} \mathrm{Cu}^{2+} \mathrm{g}^{-1}$ tuff. The intensification of the diffusion 
inside of the tuff structure can explains the favorable effect of high temperature on the adsorption capacity. Also, it reflects that the copper adsorption on studied tuff is based on low activate chemosorption process. Starting from the equilibrium constant ${ }^{[9-11]}$ :

$\mathrm{k}_{\mathrm{c}}=\frac{\mathrm{F}_{\mathrm{e}}}{1-\mathrm{F}_{\mathrm{e}}}=\frac{\mathrm{c}_{\mathrm{O}}-\mathrm{c}}{\mathrm{c}}$

where:

$\mathrm{k}_{\mathrm{c}}$ the equilibrium constant, [adimensional]

$\mathrm{F}_{\mathrm{e}}$ the adsorbed fraction at equilibrium, [adimensional]

$\mathrm{c}_{\mathrm{o}}$ the initial copper concentration in solution, $\left[\mathrm{mg} \mathrm{Cu}^{2+} \mathrm{L}^{-1}\right.$ ]

c the copper concentration at equilibrium state, $\left[\mathrm{mg} \mathrm{Cu}^{2+} \mathrm{L}^{-1}\right.$ ]

The thermodynamic parameters of the copper adsorption on volcanic tuff were calculated as follows:

$\Delta \mathrm{G}=-\mathrm{R} \cdot \mathrm{T} \cdot \ln \mathrm{k}_{\mathrm{C}}$

$\Delta \mathrm{H}=\frac{2.303 \cdot \mathrm{R} \cdot \mathrm{T}_{1} \cdot \mathrm{T}_{2}}{\mathrm{~T}_{1}-\mathrm{T}_{2}} \ln \frac{\mathrm{k}_{\mathrm{cT}}}{\mathrm{k}_{\mathrm{cT}}}$

where:

$\Delta \mathrm{G}$ the variation of free energy, [KJ mol- $\left.{ }^{1}\right]$

$\Delta \mathrm{H}$ the variation of adsorption enthalpy, [ $\mathrm{KJ} \mathrm{mol}^{-1}$ ]

$\Delta \mathrm{S}$ variation of adsorption entrophy, $\left[\mathrm{KJ} \mathrm{mol} \cdot \mathrm{K}^{-1}\right]$

$\mathrm{T}$ temperature, $[\mathrm{K}]$

$\mathrm{R}$ gas constant, $\left[8.31433 \mathrm{~J} \mathrm{~mol} \cdot \mathrm{K}^{-1}\right.$ ]

In Fig. 2 and 3 are presented the influence of the tuff's activation conditions on the enthalpy and free energy of the adsorption process. Based on these, some particularly conclusions can be advanced:

In case of volcanic tuff activated with 0.1-2 mol L-1 increasing concentrations solutions of $\mathrm{NaCl}$ the values of free energy decrease in range of $-4.97 \mathrm{KJ} \mathrm{mol}^{-1} \div-9.06 \mathrm{KJ} \mathrm{mol}^{-1}$. It indicates that the adsorption process will occur faster as the concentrations of activation solutions will be higher. Physically point of view, it is equivalent with an advanced replacement of alkaline and alkaline-earth cations from the tuff's native structure. The affinity of volcanic tuff for $\mathrm{Na}^{+}$rather than $\mathrm{H}^{+}$is proved by the higher values of free energy obtained in case of volcanic tuff activated with $\mathrm{HCl}$ solutions.

The enthalpy of the adsorption process is higher as the activation solutions 'concentrations increase. Also, the more concentrated are the activation solutions the more endothermic is copper adsorption process.

The both variations of enthalpy and free energy of the adsorption process with concentration of activation solutions indicate the energetically non-homogeneity of

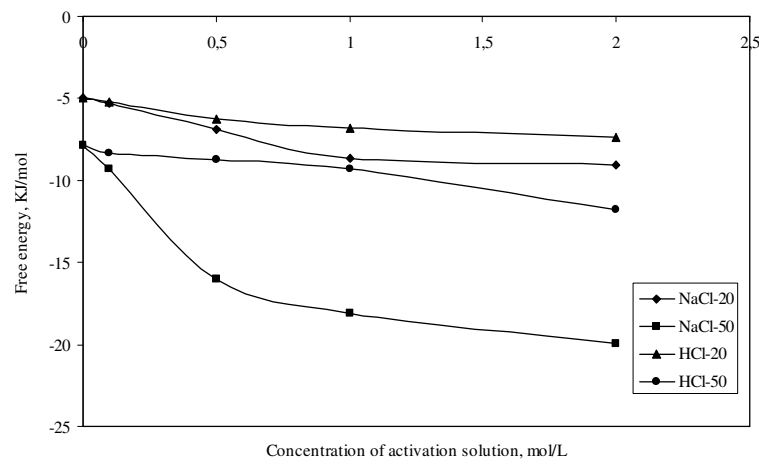

Fig. 3:The free energy of the copper adsorption process on volcanic tuff

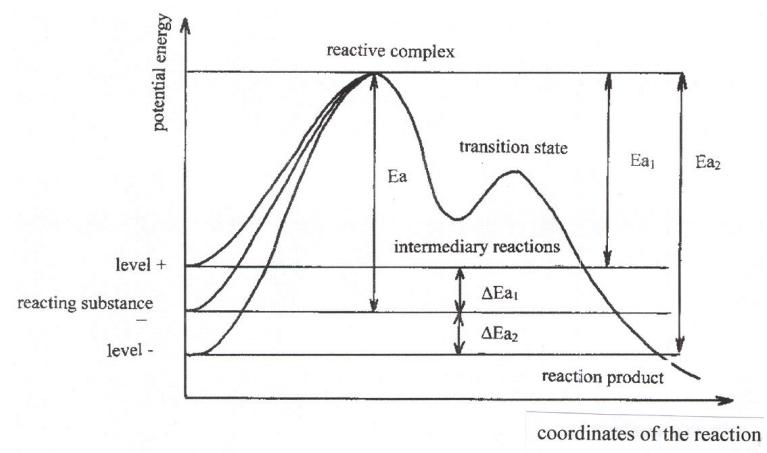

Fig. 4:Potential energy diagram for a two stage process with a slow rate stage

the adsorption active centers located on the surface of the tuff. In confirming of this hypothesis the apparent activation energy of the process was calculated. For this end, the adsorption process was considered to occur like a low activated chemosorption (absorption), represented by the reaction:

$\mathrm{RX}_{2}+\mathrm{Cu}^{2+} \rightarrow \mathrm{RCu}+2 \mathrm{X}^{+}$

and described by the kinetic equation ${ }^{[12]}$ :

$v=k \cdot c^{n}$

where:

$\mathrm{RX}_{2}$ the volcanic tuff before the adsorption of copper ions

$\mathrm{RCu}$ the volcanic tuff after the adsorption of copper ions

$\mathrm{V}$ the reaction rate, $\left[\mathrm{mol} \mathrm{Cu}{ }^{2+} \min \cdot \mathrm{L}^{-1}\right]$

$\mathrm{C}$ the copper concentration in solution, $\left[\mathrm{mol} \mathrm{Cu}{ }^{2+} \mathrm{L}^{-1}\right.$ ]

$\mathrm{n}$ the partial reaction order reported to copper, [adimensional]

$\mathrm{k}$ the reaction constant which includes the ratio tuff weight/contact solution weight, [adimensional]

Starting from the values calculated at two different temperatures, the apparent activation energy of the process can be determined using the equation ${ }^{[13]}$ : 


$$
\mathrm{E}_{\mathrm{a}}=\frac{\mathrm{R} \cdot \mathrm{T}_{1} \cdot \mathrm{T}_{2}}{\mathrm{~T}_{1}-\mathrm{T}_{2}} \cdot \ln \frac{\mathrm{k}_{1}}{\mathrm{k}_{2}}
$$

where:

$\mathrm{E}_{\mathrm{a}} \quad$ apparent activation energy, $\left[\mathrm{KJ} \mathrm{mol}^{-1}\right]$

$\mathrm{T}_{1}, \mathrm{~T}_{2}$ work temperature, $[\mathrm{K}]$

$\mathrm{k}_{1}, \mathrm{k}_{2}$ the values of reaction constant at $\mathrm{T}_{1}$ and $\mathrm{T}_{2}$, $\left[\mathrm{L}^{\mathrm{n}-1} \cdot \mathrm{mol}^{1-\mathrm{n}} \cdot \mathrm{min}^{-1}\right]$

Using the TURBO-PASCAL computer program, the values for partial reaction orders, reaction constants and apparent activation energy have been calculated.

The values of partial reaction orders in range of $0.8545-0.9368$ (Table 3) present the kinetic model for the adsorption process as being as pseudo-order 1. Also, a decrease of the apparent activation energy with the increase of the activation solutions' concentrations is observed.

In the Arrhenius expression for the reaction constant:

$\mathrm{k}=\mathrm{k}_{0} \cdot \mathrm{e}^{-\frac{\mathrm{E}_{\mathrm{a}}}{\mathrm{R} \cdot \mathrm{T}}}$

where:

$\mathrm{k}_{\mathrm{o}} \quad$ pre-exponential term, $\left[\mathrm{L}^{\mathrm{n}-1} \cdot \mathrm{mol}^{1-\mathrm{n}} \cdot \mathrm{min}^{-1}\right]$

the expression:

$X_{T}=e^{-\frac{E_{a}}{R \cdot T}}$

is named „Boltzmann factor" ${ }^{\text {, }[13]}$ and represents, physically speaking, the fraction of molecules with the energy level higher than $E_{a}$ and more preciselly, the active molecules capable to develop the chemical reaction. In case of our adsorption process, the Boltzmann factor represents the fraction of active centers (active sites) on the surface of the tuff, characterized by the $E_{a}$ potential energy beeing capable to adsorb the copper ions.

The Fig. 4 presents the potential energy diagram of two stages process, one of these considered slow rate stage. The activation energy is calculated as difference between the energy of activated complex and reactings energy (the complex site-copper ions). As we mentioned before, the high concentrations of activation solutions are reflected in low values of apparent activation energy corresponding to high specific adsorption. The decrease of apparent activation energy is represented in Fig. 4 by the curve corresponding to $\mathrm{Ea}_{1}$ energy for $\mathrm{R}+$ level of reactings. For this varation, an hypothetis which can be formulated, based on the energetic changes of the sites from the surface of the adsorbant, in parallel with contant maintaining of the activated complex's energy (represented by the pick of

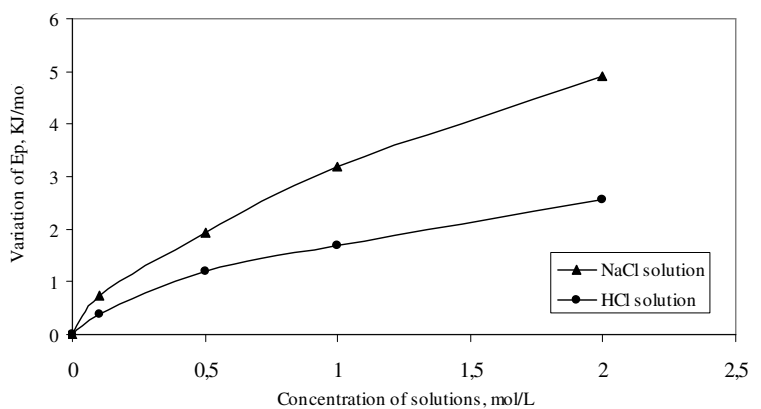

Fig. 5:The influence of activation solutions' concentrations on the potential energy of the adsorption process

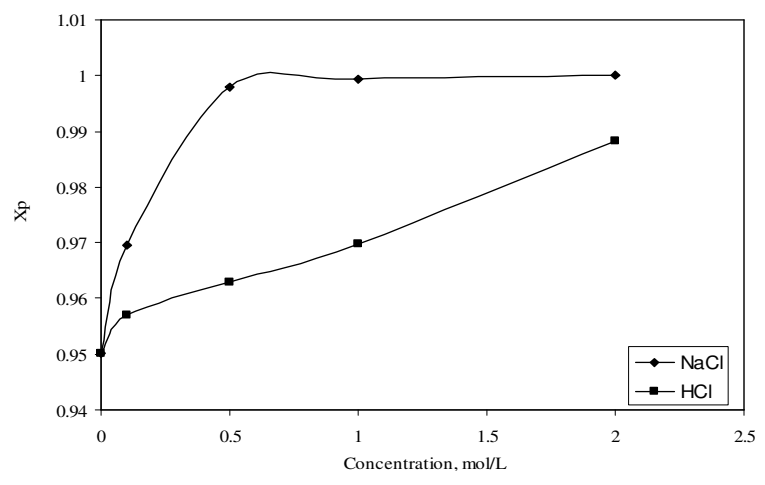

Fig. 6: The influence of activation solutions' concentrations on the active center fraction

the potential energy curve), because of the replacement the ions from the adsorbant surface. As consequence, the idea of increasing the potential energy of the adsorbant surface' sites can be advanced, simultaneously with the increase the number of active centers for adsorption of copper ions.

The difference between the apparent activation energies for cases of copper adsorption on the native tuff and activated tuff with $\mathrm{NaCl}$ and $\mathrm{HCl}$ solutions, supports the hypothetis above presented. Because of these increase of potential energy, an additional number of active centers will have the energy required to reach the energetic level of activated complex and will be capable to adsorb the copper ions. The fraction of these active centers, can be quatified in two ways:

1. Using Boltzmann factor (equation 7).

2. Starting from experimental adsorption, the fraction of active centers, $X_{p}$, can be calculated (in case of maximum specific adsorption-recorded at $2 \mathrm{~mol} \mathrm{~L}^{-1} \mathrm{NaCl}$ solution, $\mathrm{pH}=5.0$ and $\mathrm{t}=50^{\circ} \mathrm{C}$ $\mathrm{X}_{\mathrm{P}}=1$ can be considered).

The Table 3 presents the calculated values of energetic parameters (apparent activation energy, $X_{T}$, Boltzmann factor, $X_{P}$ and $\Delta E_{a}$ ) for both cases of tuff activated with $\mathrm{NaCl}$ and $\mathrm{HCl}$ solutions. In Fig. 5 and 6 are presented the variation of potential energy of active centers and the fraction of active centers on the tuff' surface with the concentration of the activation solutions. 


\section{CONCLUSION}

Based from the aspects presented above, we can conclude the follows:

1. Direct correlation between the activation solution's concentrations and the specific adsorption of copper ions.

2. Adsorption process of copper ions on the analyzed volcanic tuff is developed under a pseudo-order 1 , which proves the interaction between an active site located on the adsorbent' surface and a copper ion from the contact solution.

3. The adsorption process is endothermic and occurs spontaneous with negative variation of free energy.

4. An increase of active centers' fraction capable to participate in the adsorption process is recorded as the concentrations of activation solutions are higher.

\section{REFERENCES}

1. Kesraoui, M. and S. Kannaghb, 1997. Performance of natural zeolites for the treatment of mixed metal-contaminated effluents. Waste Manage. Res., 37: 383-394.

2. Martin, G., 1984. Removal of heavy metals from water by means of natural zeolites. Water Res., 18: 1501-1507.

3. Peri, J., M. Trgo and N. Medvidovi, 2004. Removal of zinc, copper and lead by natural zeolites. Comparison of adsorption isotherms. Water Res., 38: 1893-1899.
4. Ouki, S.K. and M. Kavannagh, 1999. Treatment of metals contaminated waters by use of natural zeolites. Water Sci. Technol., 39: 115-122.

5. Le van Mao, R.C., 1997. Zeolite materials with enhanced ion exchange capacity. Zeolites, 18: 233-239.

6. Stoici, S.D. and I. Bedelean, 1984. Zeolites, Technical Edn., Bucharest, pp: 13-38.

7. Hernandez, M.A., 2000. Adsorption characteristics of natural erionite, clinoptilolite and modernite zeolites from Mexico. 6: 33-45.

9. Baciu, D., M. Morar and L. Mihaly, 1996. Treatment of acide mine drainage from Baia Borşa mining district. Treatment's Investigation, S.C.I.C.P.M.- S.A. Baia Mare, 126, C3007, Laboratory Stage.

9. Panayotova, M.I., 2001. Kinetics and thermodynamics of copper ions removal from wastewater by use of zeolite. Waste Manage., 21: 671-676.

10. Bekta, N. and S. Kara, 2004. Removal of lead from aqueous solution by natural clinoptilolite: Equilibrium and kinetic studies. Separation and Purification Technol., 39: 189-200.

11. Komarneni, S., 1985. Heavy metal removal from aqueous solutions by tobermorites and zeolites. Nucl. Chem. Waste Manage., 5: 247-250.

12. Baldea, I., 2002. Chemical Kinetics. Cluj Napoca (Romania) University Press, pp: 102-135.

13. Murgulescu, I., T. Oncescu and E. Segal, 1981. Physical Chemistry. Roumanian Academy Ed. Bucharest, pp: 757-813. 